\title{
Location of School: Impact on Secondary Students' Performance in Mathematics
}

\author{
Usashi Kundu (De) \\ Department of Education, Diamond Harbour Women's University, Sarisha, West Bengal-743368, India \\ *Email: usashik@gmail.com
}

\section{ARTICLE INFORMATION}

Received: October 18, 2018

Revised: December 21, 2018

Accepted: February 27, 2019

Published online: March 04, 2019

Keywords:

Performance in mathematics, Locational variable

DOI: 10.15415/iie.2019.71003

\section{Introduction}

The National Policy of Education (1986) has envisaged that "Mathematics should be visualized as the vehicle to train a child to think, reason, analyse, and to articulate logically. Apart from being a specific subject, it should be treated as a concomitant to any subject involving analysis and reasoning. With the recent introduction of computers in schools, educational computing, and the emergence of learning through the understanding of cause-effect relationships and the interplay of variables, the teaching of mathematics will be suitably redesigned to bring it in line with modern technological devices" (NPE-1986). The National Curriculum Framework for School Education (NCFSE-2005) reiterates the importance of mathematics education as visualized by NPE-1986. According to NCFSE-2005, the main goal of mathematics education is to develop children's abilities for mathematisation. It has also been pointed out that the aim of school mathematics to develop "useful" capabilities, particularly those relating to numeracy, that is, numbers, number operations, measurements, decimals, and percentages, is narrow. The higher aim is to nurture the child's resources to think and reason mathematically, to pursue assumptions to their logical conclusion, and to handle abstraction. It includes a way of doing things, and the ability and attitude to formulate and solve problems (Pal, 2005). The study of mathematics is a prerequisite for the development of the learners' power of abstraction and reasoning (Kilpatrick, 2008).

Kothari Commission (1964-66) recommended mathematics as a compulsory subject for all school students (Ravindra, 2007). Mathematics is both a central component of the school curriculum for all pupils and a discipline typically seen as formidable and esoteric. Therefore, ignorance of mathematics will be a great handicap in the progress of one's study in many other subjects. It is one of the most important subjects for most vocational choices (Cesar, 2002). It is a subject from which other sciences draw inspiration and substance. A sound background of mathematics is a necessary condition for the study of sciences and science related subjects (Eraikhuemen, 2003).

\section{Significanc of the Study}

Despite efforts throughout the $20^{\text {th }}$ century to make school mathematics more attractive and accessible, inadequate performance in mathematics is still 
prevalent among pupils which deny their entry to further study that would lead to various careersand educational opportunities. The slogan "mathematics for all" has been widely promoted from the last decades of the $20^{\text {th }}$ century, giving rise to disputes among mathematicians, educators, parents, and the public over how much attention should be placed in the curriculum for practising routine procedures, solving practical problems by applying mathematics, learning about the historical and cultural sources of mathematical ideas, discussing the results of one's mathematical investigations, learning definitions and proving theorems, or even using mathematics to challenge the social order. Although mathematics is almost universally considered to be an important school subject, it often becomes increasingly disliked and even feared as learners discover that it is being used to control their educational progress (Kilpatrick, 2008).

In the present day, the examination results of different school boards of India in general and West Bengal in particular are not much satisfactory in respect of performance in mathematics. Students' learning outcomes in the secondary stage reveal an academic gap of expected performance in the various branches of mathematics. In response to this gap in performance and to the implied deficiency in learning, this study endeavours to analyse whether location of school could be a contributory factor in mathematics performance of their secondary students.
Schools from both Kolkata and outskirts have been included in the study. Schools situated in areas just outside greater Kolkata, as per the notification given by Kolkata Municipal Corporation have been operationally defined in this study as schools from outskirts.

\section{Objective of the Study}

The study attempts to examine whether the location of school has any impact on students' performancein mathematics.

\section{Hypothesis}

$\mathrm{H}_{0} 1$ There is no significant difference between the mean scores in mathematics in Madhyamik Examination obtained by the students of Kolkata and outskirts.

\section{Method}

\subsection{Research Design}

Ex post facto research design has been employed in carrying out the study.

\subsection{Sample and Sampling Technique}

The scores in mathematics of 1104 Madhyamik examinees from six secondary schools of Kolkata and outskirts in 4 consecutive years served as the source of data and the sampling technique used was purposive. The profile of candidates appearing from each school is summarized in Table 1.

Table 1: Profile of candidates appearing in the Madhyamik examination from different schools

\begin{tabular}{|c|c|c|c|c|c|c|c|c|c|}
\hline \multirow[t]{2}{*}{$\begin{array}{l}\text { School } \\
\text { Number }\end{array}$} & \multirow[t]{2}{*}{ Location of School } & \multirow{2}{*}{\multicolumn{2}{|c|}{$\begin{array}{l}\text { Type of School } \\
2005\end{array}$}} & \multicolumn{4}{|c|}{$\begin{array}{l}\text { Number of Candidates Appearing in the } \\
\text { Madhyamik Examination }\end{array}$} & \multirow{2}{*}{$\begin{array}{l}\text { Total } \\
\text { 2005-2008 }\end{array}$} & \multirow[t]{2}{*}{ Total } \\
\hline & & & & 2006 & 2007 & 2008 & 2005-2008 & & \\
\hline 1 & Kolkata & \multicolumn{2}{|l|}{ Boys } & 87 & 105 & 110 & 81 & 383 & \multirow{2}{*}{505} \\
\hline 2 & Kolkata & \multicolumn{2}{|l|}{ Girls } & 32 & 39 & 26 & 25 & 122 & \\
\hline \multirow{2}{*}{3} & \multirow{2}{*}{ Outskirts } & \multirow{2}{*}{ Co-educational } & Boys & 22 & 15 & 21 & 14 & 72 & \multirow{7}{*}{599} \\
\hline & & & Girls & 09 & 16 & 12 & 11 & 48 & \\
\hline \multirow{2}{*}{4} & \multirow{2}{*}{ Outskirts } & \multirow{2}{*}{ Co-educational } & Boys & - & - & - & 16 & 16 & \\
\hline & & & Girls & - & - & - & 11 & 11 & \\
\hline \multirow{2}{*}{5} & \multirow{2}{*}{ Outskirts } & \multirow{2}{*}{ Co-educational } & Boys & - & 67 & 51 & 76 & 194 & \\
\hline & & & Girls & - & 65 & 42 & 55 & 162 & \\
\hline 6 & Outskirts & \multicolumn{2}{|l|}{ Boys } & 24 & 31 & 27 & 14 & 96 & \\
\hline \multicolumn{4}{|l|}{ Total } & 174 & 338 & 289 & 303 & 1104 & 1104 \\
\hline
\end{tabular}




\subsection{Procedure}

To collect data in relation to Madhyamik Examination, which is a school leaving examination conducted by the West Bengal Board of Secondary Education, the heads of 10 schools in Kolkata and outskirts were approached at first and the purpose and relevance of the study were explained. But only six of them gave permission to use their school record as a source of data for this study. Hence, from these six schools, in respect of every candidate the following information was recorded:

- Serial number of candidate,

- Name of school (code has been used),

- Type of school (boys/ girls/ co-educational),

- Location of school (Kolkata/ outskirts),
- Year of appearance in Madhyamik Examination (code has been used),

- Gender of the candidate,

- Score obtained in mathematics,

The entire exercise took around a month to complete. When the sessions were completed, the head of the institutions and the nonteaching staffs were thanked for their eagerness and help.

\section{Data Analysis and Interpretation}

Table 2 describes the mean scores in mathematics for various groups and subgroups, with standard deviation indicated and sample size given underneath.

Table 2: Mean $(M)$ and standard deviation $(S D)$ of mathematics scores of different sections of Madhyamik candidates along with the relevant sample size $(n)$

\begin{tabular}{|c|c|c|c|c|c|c|}
\hline Location & Gender & 2005 & 2006 & 2007 & 2008 & 2005-2008 \\
\hline \multirow{3}{*}{ Kolkata } & Male & $\begin{array}{l}M=44.84 S D=15.30 \\
n=87\end{array}$ & $M=42.06 S D=17.93 n=105$ & $M=47.39 S D=19.39 n=110$ & $\begin{array}{l}M=54.11 S D=22.47 \\
n=81\end{array}$ & $M=46.77 S D=19.28 n=383$ \\
\hline & Female & $\begin{array}{l}M=21.63 S D=11.37 \\
n=32\end{array}$ & $M=21.64 S D=12.40 n=39$ & $M=25.73 S D=9.43 n=26$ & $M=29.44 S D=11.25 n=25$ & $M=24.11 S D=11.62 n=122$ \\
\hline & Both & $\begin{array}{l}M=38.60 S D=17.65 \\
n=119\end{array}$ & $M=36.53 S D=18.91 n=144$ & $M=43.25 S D=19.82 n=136$ & $M=48.29 S D=22.90 n=106$ & $M=41.30 S D=20.21 n=505$ \\
\hline \multirow{3}{*}{ Outskirts } & Male & $\begin{array}{l}M=27.13 S D=12.49 \\
n=46\end{array}$ & $M=27.48 S D=17.16 n=113$ & $\begin{array}{l}M=27.64 S D=15.30 \\
n=99\end{array}$ & $\begin{array}{l}M=36.01 S D=16.98 \\
n=120\end{array}$ & $M=30.19 S D=16.55 n=378$ \\
\hline & Female & $\begin{array}{l}M=19.78 S D=10.96 \\
n=09\end{array}$ & $M=26.02 S D=9.08 n=81$ & $\begin{array}{l}M=28.24 S D=10.94 \\
n=54\end{array}$ & $M=28.09 S D=13.05 n=77$ & $M=27.03 S D=11.19 n=221$ \\
\hline & Both & $\begin{array}{l}M=25.93 S D=12.46 \\
n=55\end{array}$ & $\begin{array}{l}M=26.87 S D=14.34 \\
n=194\end{array}$ & $\begin{array}{l}M=27.85 S D=13.88 \\
n=153\end{array}$ & $\begin{array}{l}M=32.91 \\
S D=16.00 n=197\end{array}$ & $M=29.02 S D=14.87 n=599$ \\
\hline
\end{tabular}

Segregated analyses for each gender, for each year as well as a combined analysis have been done. Independent samples $t$-test for equality of means for mathematics scores of students from Kolkata and from outskirts has been conducted. The results of the $t$-tests are summarized in Table 3. In this table, $p$-values smaller than .01 are printed in bold, while those smaller than .05 are printed in italics. 
Table 3: Statistical comparison of mathematics scores of Madhyamik candidates from Kolkata and outskirts for different years

\begin{tabular}{|c|c|c|c|c|c|c|c|c|}
\hline Year & Gender & $\begin{array}{l}\text { Sample Size } \\
\text { of Students } \\
\text { from Kolkata }\end{array}$ & $\begin{array}{l}\text { Sample Size } \\
\text { of Students } \\
\text { from } \\
\text { Outskirts }\end{array}$ & $\begin{array}{l}\text { Mean Score of } \\
\text { Students from } \\
\text { Kolkata }\end{array}$ & $\begin{array}{l}\text { Mean Score } \\
\text { of Students } \\
\text { from } \\
\text { Outskirts }\end{array}$ & $\begin{array}{l}p \text {-value of } \\
\text { Levene's Test } \\
\text { for Equality of } \\
\text { Variances }\end{array}$ & $t$ Test Used & $\begin{array}{l}p \text {-value of } \\
\text { Appropriate } \\
t \text { Test }\end{array}$ \\
\hline \multirow{3}{*}{2005} & Male & 87 & 46 & 44.84 & 27.13 & .304 & $\begin{array}{l}\text { Equal } \\
\text { Variance }\end{array}$ & .000 \\
\hline & Female & 32 & 9 & 21.63 & 19.78 & .539 & $\begin{array}{l}\text { Equal } \\
\text { Variance }\end{array}$ & .667 \\
\hline & Both & 119 & 55 & 38.60 & 25.93 & .029 & $\begin{array}{l}\text { Unequal } \\
\text { Variance }\end{array}$ & .000 \\
\hline \multirow{3}{*}{2006} & Male & 105 & 113 & 42.06 & 27.48 & .339 & $\begin{array}{l}\text { Equal } \\
\text { Variance }\end{array}$ & .000 \\
\hline & Female & 39 & 81 & 21.64 & 26.02 & .053 & $\begin{array}{l}\text { Equal } \\
\text { Variance }\end{array}$ & .030 \\
\hline & Both & 144 & 194 & 36.53 & 26.87 & .000 & $\begin{array}{l}\text { Unequal } \\
\text { Variance }\end{array}$ & .000 \\
\hline \multirow{3}{*}{2007} & Male & 110 & 99 & 47.39 & 27.64 & .008 & $\begin{array}{l}\text { Unequal } \\
\text { Variance }\end{array}$ & .000 \\
\hline & Female & 26 & 54 & 25.73 & 28.24 & .330 & $\begin{array}{l}\text { Equal } \\
\text { Variance }\end{array}$ & .319 \\
\hline & Both & 136 & 153 & 43.25 & 27.85 & .000 & $\begin{array}{l}\text { Unequal } \\
\text { Variance }\end{array}$ & .000 \\
\hline \multirow{3}{*}{2008} & Male & 81 & 120 & 54.11 & 36.01 & .000 & $\begin{array}{l}\text { Unequal } \\
\text { Variance }\end{array}$ & .000 \\
\hline & Female & 25 & 77 & 29.44 & 28.09 & .662 & $\begin{array}{l}\text { Equal } \\
\text { Variance }\end{array}$ & .644 \\
\hline & Both & 106 & 197 & 48.29 & 32.91 & .000 & $\begin{array}{l}\text { Unequal } \\
\text { Variance }\end{array}$ & .000 \\
\hline \multirow{3}{*}{$\begin{array}{l}2005- \\
2008\end{array}$} & Male & 383 & 378 & 46.77 & 30.19 & .001 & $\begin{array}{l}\text { Unequal } \\
\text { Variance }\end{array}$ & .000 \\
\hline & Female & 122 & 221 & 24.11 & 27.03 & .408 & $\begin{array}{l}\text { Equal } \\
\text { Variance }\end{array}$ & .023 \\
\hline & Both & 505 & 599 & 41.30 & 29.02 & .000 & $\begin{array}{l}\text { Unequal } \\
\text { Variance }\end{array}$ & .000 \\
\hline
\end{tabular}

It is seen that the effect of location of school on performance in mathematics is significant at $1 \%$ level when both the genders are combined for all the four years separately, that is, 2005, 2006, 2007, and 2008. The $p$-value is also significant when both the genders are considered together for the total period of 20052008. Therefore, the hypothesis $\mathrm{H}_{0} 1$ is rejected at $1 \%$ level in all these above cases. Students from Kolkata have significantly higher mean scores than students from outskirts in all the four years. The effect of location of school is significant at $1 \%$ level for boys in all the four years, namely, 2005, 2006, 2007, and 2008 (i.e., the hypothesis $\mathrm{H}_{0} 1$ is also rejected at $1 \%$ level in all these cases). Boys from Kolkata have significantly higher mean scores than boys from outskirts in all the four years. However, the hypothesis $\mathrm{H}_{0} 1$ is not rejected in the case of girls, as no significant difference has been found between the mathematics scores of girls from Kolkata and outskirts for 2005, 2007, and 2008. In case of 2006, this difference has been found to be 
significant at 5\% level (but not at $1 \%$ level). It may be noted that the sample size for girls was the highest for this year.

\section{Discussion}

The present study reveals that students from Kolkata schools score better in mathematics than the students from the schools that are situated in the outskirts. It is quite natural that the infrastructural facilities of the schools located in a metropolitan city like Kolkata are much richer than the facilities that the outskirt schools enjoy. City schools have better access to internet from which their counterparts are often deprived. The finding of the present study resulted in some commonalities and some deviations from the prior researches in this context. The result is consistent with the results of the studies carried out by Mehera (2004), Elijio and Dudaite (2005), and Vijayalakshmi and Lavanya (2006), where it is shown that there are statistically significant differences between the average performance of students in mathematics in urban and rural communities. Performances of students from urban communities are statistically significantly higher than their peers in the rural communities. Students studying in urban locality colleges have higher mathematics performance when compared to semiurban and rural localities (Vijayalakshmi \& Lavanya, 2006). However, the finding is in contradiction to the result of the study undertaken by Thirunarayanan (2004) where it was showed that students in centralcity schools in the United States perform statistically "significantly worse" in many subject areas than the students in suburban schools. Likewise, Lamb and Fullarton (2001) showed that in both United States and Australia, students in schools in rural locations achieve higher in mathematics than students in city and urban areas.

\section{Implication of the Study}

The result of the study has an important implication for mathematics education because the finding reveals a serious aspect that is crucial for understanding the nature of performance of students in mathematics in the secondary stage. It recommends that schools located in the outskirts should be provided with better infrastructure to help in better performance of their students in mathematics. Administrators, policy makers, politicians, and mathematics educators could feel justified in trying to find out ways to narrow the gap in mathematics performance between urban students and their counterparts by taking active involvement in increasing curricular and other facilities indirectly related to the curriculum among the schools situated outside the metropolitan cities.

\section{Acknowledgements}

Prof. Debjani Sengupta, Former Professor, Department of Education, University of Calcutta, India

Prof. Debasis Sengupta, Professor, Applied Statistics

Division, Indian Statistical Institute, Kolkata, India

\section{References}

Cesar, M. (2002). Peer Interactions in Mathematics Classes: A Bridge between Ideals and Practices of Inclusive Schooling. In S. C. Agarkar \& V. D. Lale (Eds.), Science, Technology and Mathematics Education for Human Development: Vol. 2. Proceedings of the CASTMEUNESCO-HBCSE. International Conference (243248). Mumbai, India: Homi Bhaba Centre for Science Education, Tata Institute of Fundamental Research.

Elijio, A., \& Dudaite, J. (2005). Social, Economical, and Educational Factors in Relation to Mathematics Achievement. Retrieved March 07, 2014, from http:// www.nec.lt/failai/256_tyrimai_timss_pub_konf_ TMDK_faktoriai.pdf.

Eraikhuemen, L. (2003). Mathematics as an Essential Tool for Universal Basic Education (UBE): Implications for Primary School Mathematics. The Journal of the Mathematical Association of Nigeria, 28(1), 1-7.

Kilpatrick, J. (2008). Mathematics. In G. McCulloch \& D. Crook (Eds.), The Routledge International Encyclopaedia of Education (372-375). Taylor \& Francis Group.

Lamb, S., \& Fullarton, S. (2001). Classroom and School Factors affecting Mathematics Achievement: A Comparative Study of the US and Australia Using TIMSS. Paper presented at the Annual Conference of the American Educational Research Association, Seattle, WA. Retrieved March 07, 2014, from http:// research.acer.edu.au/timss_monographs/10

Mehera, C. (2004). A Study on the Achievement at the Secondary Level and Some of Its Determinants. Indian Educational Abstract, 5(1 \& 2), 10-11.

National Policy on Education (NPE). (1986). Reorienting the Content and Process of Education (Part VIII). 
Government of India. Retrieved March 07, 2014, from http://www.educationforallinindia.com/page 57. html.

Pal, Y. (2005). National Curriculum Framework. New Delhi, India: NCERT. Retrieved March 07, 2014, from

http://www.ncert.nic.in/rightside/links/pdf/ framework/english/nf2005.pdf.

Ravindra, C. (2007). Researchers on Curriculum and Teaching: Mathematics. In S. Uppal, \& G. Ram (Eds.),
Sixth Survey of Educational Research (1993-2000) (Vol. II, 362-376). New Delhi, India: NCERT.

Thirunarayanan, M. O. (2004). The "Significantly Worse" Phenomenon: A Study of Student Achievement in Different Content Areas by School Location. Education and Urban Society, 36(4), 467-481.

Vijayalakshmi, G., \& Lavanya, P. (2006). Relationship between Stress and Mathematics Achievement among Intermediate Students. Edutracks, 5(11), 34-37.

\section{旬 CHITKARA}

\section{Issues and Ideas in Education}

Chitkara University, Saraswati Kendra, SCO 160-161, Sector 9-C, Chandigarh, 160009, India

\section{Volume 7, Issue 1}

March 2019

ISSN 2320-7655

Copyright: [ $@ 2019$ Usashi Kundu (De)] This is an Open Access article published in Issues and Ideas in Education (Issues Ideas Educ.) by Chitkara University Publications. It is published with a Creative Commons AttributionCC-BY 4.0 International License. This license permits unrestricted use, distribution, and reproduction in any medium, provided the original author and source are credited. 